\title{
Congenital adrenal hyperplasia with an ovarian adrenal rest tumor: a case report
}

\author{
Betül Aydın Buyruk ${ }^{1 \oplus}$, Göknur Yorulmaz ${ }^{1} \oplus$, Ayşe Nur Değer $^{2} \odot$, Medine Nur Kebapçı $^{1} \odot$ \\ ${ }^{1}$ Department of Endocrinology, Osmangazi University School of Medicine, Eskişehir, Turkey \\ ${ }^{2}$ Department of Endocrinology, Dumlupınar University, Kütahya Evliya Çelebi Training and Research Hospital, Kütahya, Turkey
}

\begin{abstract}
Adrenal rest tumors (ART) are extra-adrenal findings of adrenal tissue. Testicular adrenal rest tumors (TART) are widespread in males with congenital adrenal hyperplasia (CAH). Ovarian adrenal rest tumours (OART), which form in females with $\mathrm{CAH}$, are less commonly seen. Reports in literature of OART are extemely rare. The case is here presented of a 43-year-old female who was diagnosed at the age of 15 years with CAH and underwent bilateral adrenalectomy at the age of 37 . On presentation at our clinic, $4 \times 2 \mathrm{~cm}$ mass was determined on the right adnexa in the advanced tests and a right-side salpingo-oopherectomy was performed. The pathology examination reported heterotopic adrenal cortical tissue. Routine ovarian imaging in females with CAH is not indicated. Although OART are rarely seen, they should be kept in mind and these patients should be evaluated radiologically together with laboratory tests.

Keywords: Ovarian adrenal rest tumor, congenital adrenal hyperplasia
\end{abstract}

$\sim$ ongenital adrenal hyperplasia $(\mathrm{CAH})$ is a group adrenal steroid synthesis disorder disease, which emerges as a result of a deficiency of one of the enzymes in the steroid synthesis pathway. More than $90 \%$ of patients are deficient in 21-hydroxylase enzyme (21OHD). A deficiency of 11-beta hydroxylase enzyme is seen in 5\%-8\% of CAH patients and is the second most common type. The disease has autosomal recessive transfer. Steroid synthesis is decreased in these patients and as a result, the adrenocorticotropic hormone (ACTH) level increases, leading to proliferation of all cells with adrenal cortex origin [1]. The clinical results are over-production of adrenal androgens with the accumulation of precursor hormones and hypertrophy of the adrenal glands [2,3]. By deviating from the androgen biosynthesis path, these precursors lead to virilisation in female fetuses or infants and with accelerated skeletal maturation in both males and females, cause rapid postnatal growth, early puberty and short adult height. While males with classic $\mathrm{CAH}$ do not show any abnormalities at birth, females are born with ambiguous genitalia [4].

ARTsare extra-adrenal findings of adrenal tissue and there is an ART in $50 \%$ of newborns with CAH. ARTs are gradually covered and prevalence falls to $1 \%$ in adulthood [5]. TART are widespread in males with $\mathrm{CAH}$, with a high prevalence of $95 \%$ reported in some studies and they can be determined at the onset of childhood [6]. TART is a benign tumour, seen bilaterally in the majority of cases [2]. OART, which form in females with $\mathrm{CAH}$, are less commonly seen and are another extra-adrenal tissue [7]. Besides 
TARTs, adrenal rests may develop elsewhere in the retroperitoneum, including the ovaries and surrounding structures. OART appear to be uncommon in women with classic $21 \mathrm{OHD}$, with none found in a systematic evaluation of 13 women [8] and only scattered cases reported in the literature [9]. The etiology appears related to sustained elevations in ACTH as a re- sult of poor compliance, as in men with TART. It is not known if glucocorticoid or mineralocorticoid therapy reduces adrenal rest development and/or size.

Reports in literature of OART are extremely rare. The case is here presented of a female diagnosed at the age of 15 years with $\mathrm{CAH}$ who underwent bilateral adrenalectomyat the age of 37 and on presentation at

Table 1. Laboratory test results

\begin{tabular}{|c|c|c|}
\hline & Result & The reference range \\
\hline $\mathrm{Na}$ & $146 \mathrm{mEq} / \mathrm{L}$ & $135-150 \mathrm{mEq} / \mathrm{L}$ \\
\hline K & $4.9 \mathrm{mEq} / \mathrm{L}$ & $3.5-5.5 \mathrm{mEq} / \mathrm{L}$ \\
\hline BUN & $20.6 \mathrm{mg} / \mathrm{dl}$ & $5-20 \mathrm{mg} / \mathrm{dl}$ \\
\hline Creatinine & $1.25 \mathrm{mg} / \mathrm{dl}$ & $0.5-1.4 \mathrm{mg} / \mathrm{dl}$ \\
\hline $\mathrm{Ca}$ & $9.09 \mathrm{mg} / \mathrm{dl}$ & $8.5-10.5 \mathrm{mg} / \mathrm{dl}$ \\
\hline $\mathrm{P}$ & $2.71 \mathrm{mg} / \mathrm{dl}$ & $2.7-4.5 \mathrm{mg} / \mathrm{dl}$ \\
\hline ALT & $12 \mathrm{U} / \mathrm{L}$ & $20-40 \mathrm{U} / \mathrm{L}$ \\
\hline AST & $18 \mathrm{U} / \mathrm{L}$ & 7-39 U/L \\
\hline Glucose & $89 \mathrm{mg} / \mathrm{dl}$ & $70-110 \mathrm{mg} / \mathrm{dl}$ \\
\hline Hemoglobin & $13 \mathrm{gr} / \mathrm{dl}$ & $12-14 \mathrm{gr} / \mathrm{dl}$ \\
\hline Prolactin & $22.63 \mathrm{ng} / \mathrm{ml}$ & $4.79-23.3 \mathrm{ng} / \mathrm{ml}$ \\
\hline FSH & $3.66 \mathrm{mIU} / \mathrm{ml}$ & $3.5-12.5 \mathrm{mIU} / \mathrm{ml}$ \\
\hline LH & $13.46 \mathrm{mIU} / \mathrm{ml}$ & $2.4-12.6 \mathrm{mIU} / \mathrm{ml}$ \\
\hline TSH & $0.70 \mathrm{uIU} / \mathrm{ml}$ & $0.27-4.2 \mathrm{uIU} / \mathrm{ml}$ \\
\hline FT4 & $1.18 \mathrm{ng} / \mathrm{dl}$ & $0.93-1.7 \mathrm{ng} / \mathrm{dl}$ \\
\hline FT3 & $3.62 \mathrm{pg} / \mathrm{ml}$ & $2-4.4 \mathrm{pg} / \mathrm{ml}$ \\
\hline $17 \mathrm{OH}-\mathrm{PG}$ & $4.57 \mathrm{ng} / \mathrm{ml}$ & $0.59-3.44 \mathrm{ng} / \mathrm{ml}$ \\
\hline Total testosterone & $256 \mathrm{ng} / \mathrm{dl}$ & $8-50 \mathrm{ng} / \mathrm{dl}$ \\
\hline Free testosterone & $4.08 \mathrm{pg} / \mathrm{ml}$ & $0.45-3.17 \mathrm{pg} / \mathrm{ml}$ \\
\hline Estradiol & $147 \mathrm{pg} / \mathrm{ml}$ & $12.5-166 \mathrm{pg} / \mathrm{ml}$ \\
\hline ACTH & $>2000 \mathrm{pg} / \mathrm{ml}$ & $7.2-63.3 \mathrm{pg} / \mathrm{ml}$ \\
\hline Cortisol & $0.895 \mathrm{ug} / \mathrm{dl}$ & $6.2-19.4 \mathrm{ug} / \mathrm{dl}$ \\
\hline
\end{tabular}

$\mathrm{Na}=$ sodium, $\mathrm{K}=$ potassium, $\mathrm{BUN}=$ blood urea nitrogen, $\mathrm{Ca}=$ calcium, $\mathrm{P}=$ phospate, $\mathrm{ALT}=$ alanine aminotransferase, $\mathrm{AST}=$ aspartate aminotransferase, $\mathrm{FSH}=$ follicle-stimulating hormone, $\mathrm{LH}=$ luteinizing hormone, $\mathrm{TSH}=$ thyroid-stimulating hormone, $\mathrm{FT} 4=$ free thyroxine, $\mathrm{FT} 3=$ free triiodothyronine, $17 \mathrm{OH}-\mathrm{PG}=$ 17 hydroxyprogesterone, $\mathrm{ACTH}=$ adrenocorticotropic hormone 
the age of 43 years, was determined with ART on the right ovary.

\section{CASE PRESENTATION}

A 43-year-old female presented at our clinic for gender re-assignment. It was learned from the patient history that from tests applied at age 15, because of absence of menarche and increased facial and chest hair, a diagnosis was made of $\mathrm{CAH}$ due to 21OHD enzyme deficiency. In the karyotype analysis, 46XX was determined. Treatment was started for the patient but the patient did not take the medication regularly or attend follow-up examinations. At the age of 37, the patient was hospitalized because of nausea, vomiting and abdominal pain. Acute renal failure was diagnosed and hemodialysis was applied. On the dynamic surrenal computed tomography (CT) examination, lobular, contoured, heterogenous structures were seen of approximately $5 \times 5 \times 6 \mathrm{~cm}$ in size in a right suprarenal localisation and of approximately $12 \times 8 \times 17$ $\mathrm{cm}$ in size in the left suprarenal location. These mass lesions were pushing both kidneys towards the inferior, in the medulla of both kidneys there were millimetric calcifications and dense soft tissue $1.5 \times 1$ $\mathrm{cm}$ was determined in the left ovary. The mass lesion identified by the radiology department may be bilateral surrenal hyperplasia with malignant transformation. Because of the tumor was thought to

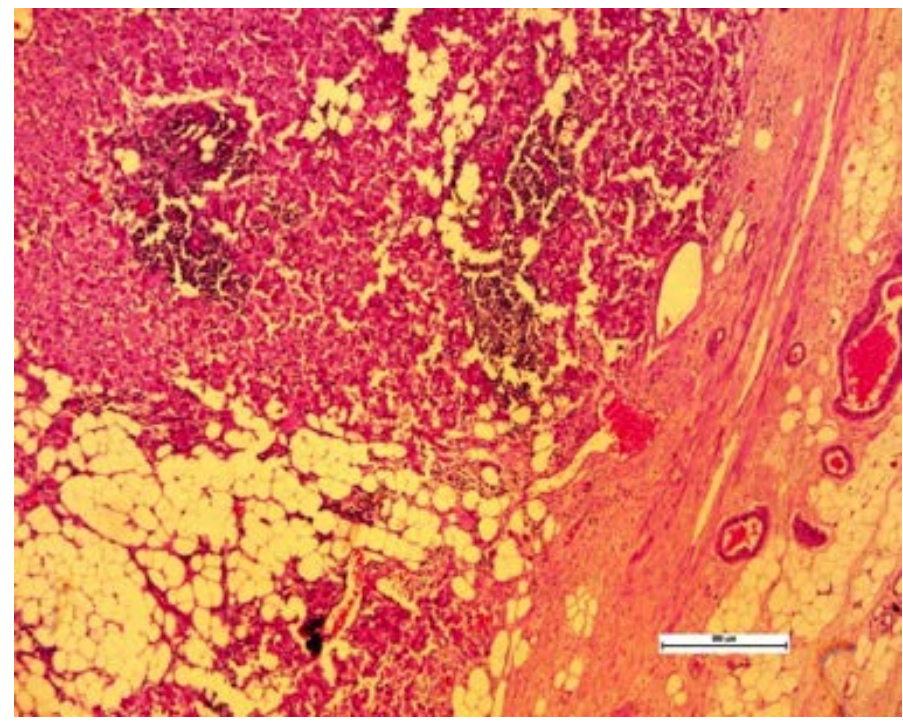

Fig. 1. Lesion with regular border separate from the tissue surrounding the ovary be bilateral adrenal hyperplasia with malignant transformation and the mass size was large and pressure to the kidney was applied, the patient had undergone bilateral surrenalectomy operation. The pathology examination was reported ascortical medullar adrenal hyperplasia containing widespread myelipomatous foci with positive vimentin and chromogranin staining. Treatment of hydrocortisone and fludrocortisone was started. After 2 weeks of hemodialysis treatment, the patient's kidney function was returned to normal.

In the physical examination at presentation, blood pressure was 110/80 $\mathrm{mmHg}$, pulse: 90 beat per minute, respiration: 20/minute. The external appearance was male phenotype. There was widespread hyperpigmentation on the skin. There was male-type hair on the chest, face and the pubis. Breast development was tanner stage 2. Other system examinations were normal. Laboratory test results at presentation were defined in Table 1.

On the abdominal ultrasonography (USG), there was an appearance of a heterogenous hyperechoic mass $48 \times 28 \times 32 \mathrm{~mm}$ in size, laterally adjacent to the uterus on the right side. On abdominal-pelvic CT, neither of the adrenal glands were observed. At the level of both adnexa, a hyperdense, nodular lesion approximately $2 \mathrm{~cm}$ in diameter was reported and at the level of the right adnexa, a hypodense area $4 \times 2 \mathrm{~cm}$ extending to the Douglas pouch. A right-side salpingooopherectomy was applied to the patient. Heterotopic

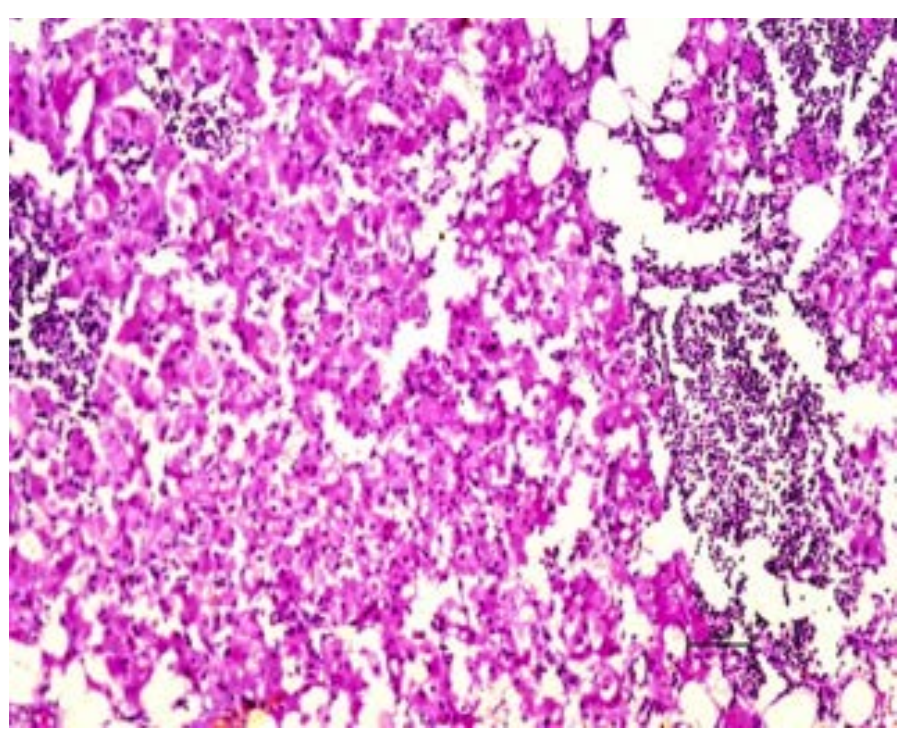

Fig. 2. Inflamed cells and mature adipocytes around heterotopic adrenal cortical cells $(\mathbf{H} \& \mathbf{E} \times \mathbf{1 0})$ 


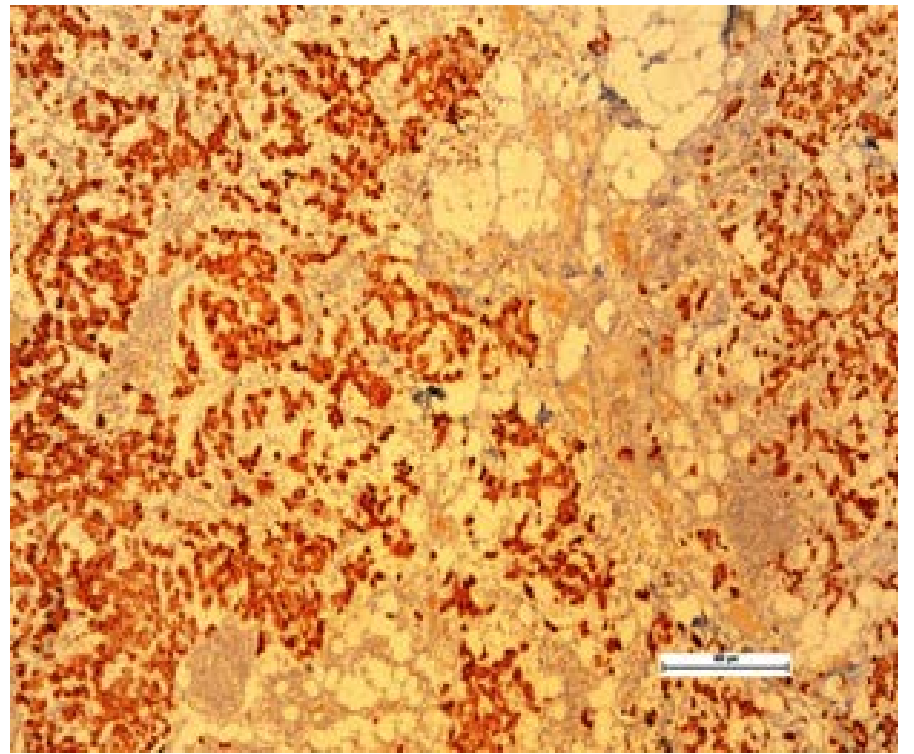

Fig. 3. Ppositive reaction with inhibin in heterotopic adrenal tissue.

adrenal cortical tissue was reported in the pathology examination. The immunohistochemical test results were determined as melen A: diffuse positive, inhibin: diffuse positive, vimentin: focal mild positive, synaptofizin negative, chromogranin: negative, CD68: negative, CD:10 negative, and $1 \%$ of proliferative index with Ki 67 (Figures 1, 2, 3, 4, and 5)

In the postoperative period, because of the patient referred to another center, she could not be followedup.

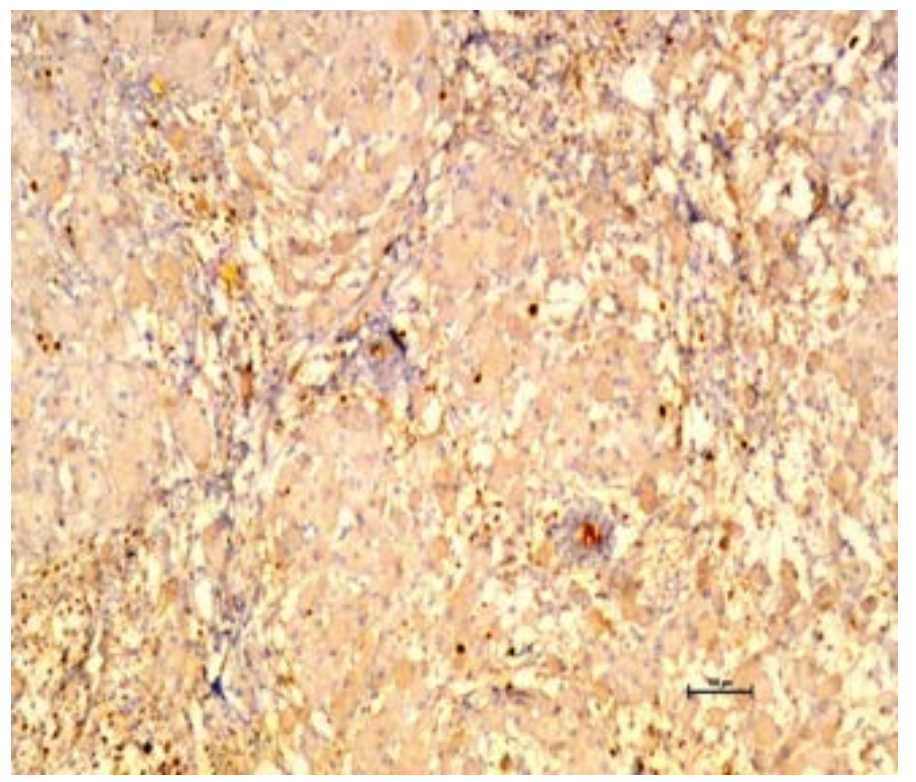

Fig. 5. 1\% proliferative index with Ki 67 in heterotopic adrenal tissue $(\mathrm{Ki67} \times \mathbf{1 0})$

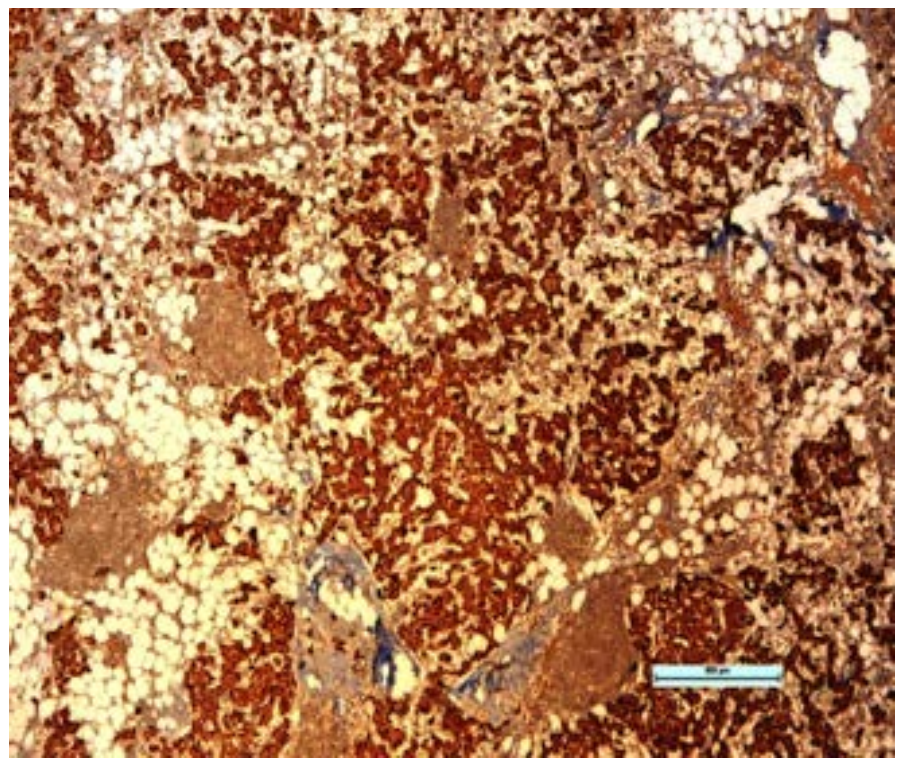

Fig. 4. Positive reaction with melen $\mathbf{A}$ in heterotopic adrenal tissue

\section{DISCUSSION}

In comparison with the high incidence rate of TART, the very low incidence rate of OART in female ovaries raises questions about the mechanisms preventing the development of OART. Val et al. [10] reported that TART develops from adrenal gland cells that have migrated to the testis or from local steroidogenic stem cells [10]. These cells express MC2R which is the ACTH receptor regulating Shh expresssion related to adrenal development and differentiation [11]. The first question to be addressed is whether or not there is similar migration of adrenallike cells in the ovaries. In inguinal-scrotal operations in male children, incidental findings have provided evidence of the migration of primordial adrenal cell cortex cells together with coelomic epithelial cells [12, 13]. These findings show that the difference between males and females in the incidence of adrenal rest tumours could be associated not with abnormal adrenal tissue migration but with the differences in ontogenesis of the gonads.

Wnt4 is one of the main transcription factors of ontogenesis in the ovaries. This factor suppresses endothelial and steroidogenic cell migration in the developing XX gonad and prevents both male-specific coelomic blood vessel formation and the production of ectopic steroids including steroidogenic CYP17A1 and HSB3B2 enzymes [14]. Functional studies have 
reported that mutations of Wnt4 do not suppress the synthesis of the androgen synthesis enzymes CYP17A1 and HSB3B2 in the human ovaries. Females with a mutation in Wnt4 have increased steroidogenic enzymes and testosterone synthesis [15]. The presence of Wnt4 in the ovaries and the absence of testes could explain the difference in adrenal tumour incidence between males and females.

In a systematic review by Tiosano et al. [9] in 2010, only 10 OART cases were reported. For the clinician, the severity of the OART must not be underestimated as misdiagnosis can be deadly [7]. However, prompt diagnosis of OART can be elusive. This raises the concern of the lack of defined criteria for a radiologic diagnosis of OART. The sensitivity of USG and magnetic resonance imaging (MRI) for detecting small ovarian rest tumors is not known, and other androgen-producing tumors of the ovary often are not found with conventional imaging studies. Thus, the true prevalence may be higher, as most tumors have been identified during surgery or at autopsy. Rest tumors occur primarily in the ovarian tissue and, less often, in the paraovarian/adnexal area [9]. Concerns have emerged related to deficiencies in the criteria defined for the radiological diagnosis of OART. Routine ovary imaging is not indicated in females with $\mathrm{CAH}$. However, when there is ovary dysfunction, ovarian radiological imaging is recommended, first with USG for the determination of OART or polycystic ovaries. Using ultrasonography and MRI, Stikkelbroeck et al. [8] attempted to establish radiologic criteria for establishing a diagnosis of OART in 13 females with CAH. However, there were no cases of OART, a testament to the low prevalence of the tumour. This is in contrast to TART where MRI and ultrasound, the preferred diagnostic modalities, readily diagnose the disease, even tumours several millimeters in diameter [16]. In a study in the USA in 2012, with cosintropin stimulus of $18 \mathrm{~F}$ marked fluoro-2-deoxy-d-glucose positron emission tomography/ computed tomography scanning, correct identification was shown of adrenal rest tissue that could not be seen with conventional imaging in $\mathrm{CAH}$ patients following adrenalectomy. Thus, it was reported that it was possible to define successful surgical resection [17]. While unfamiliarity with the diagnosis of OART may lead to surgical treatment that may not be necessary, the large size of the tumour coupled with lack of outcome data may justify removal in some instances. With the advancement in our understanding of how OART present and the natural history of these benign tumours, the possibility arises that organ-sparing protocols can be developed, similar to the treatment of TART [18].

\section{CONCLUSION}

In our case, there was adrenal steroid synthesis following bilateral adrenalectomy. Ectopic adrenal rest tissue can cause clinical symptoms. Firstly, ectopic adrenal cells can be hormonally active and can undertake pathological steroid production in $\mathrm{CAH}$ patients. This may cause increased adrenal steroid levels postoperatively in adrenalectomy patients in particular. Secondly, there may be malignant degeneration of adrenal rest tissue. However, there is no information available in the literature. Surgical treatment for OART remains unclear due to the rarity of these tumours. For girls and women with $\mathrm{CAH}$ for whom medical treatment is unavailable or who are noncompliant with their therapy, OART should be considered when ovarian masses are detected. If an OART is detected early enough and glucocorticoid therapy is received, it is possible that the OART will decrease in size following suppression of ACTH levels. There is a need for further studies to determine whether regular screening is of benefit or not for these tumours.

\section{Informed consent}

Written informed consent was obtained from the patient for publication of this case report and any accompanying images.

\section{Conflict of interest}

The authors declared that there are no potential conflicts of interest with respect to the research, authorship, and/or publication of this article.

\section{REFERENCES}

1. Claahsen-van der Grinten HL, Otten BJ, Takahashi S, Meuleman EJ, Hulsbergen-van de Kaa C, Sweep FC, et al. 
Testicular adrenal rest tumors in adult males with congenital adrenal hyperplasia: evaluation of pituitary-gonadal function before and after successful testissparingsurgery in eight patients. J Clin Endocrinol Metab 2007;92: 612-5.

2. Claahsen-van der Grinten HL, Otten BJ, Stikkelbroeck MM, Sweep FC, Hermus AR. Testicular adrenal rest tumours in congenital adrenal hyperplasia. Best Pract Res Clin Endocrinol Metab 2009;23:209-20.

3. Stikkelbroeck NM, Otten BJ, Pasic A, Jager GJ, Sweep CG, Noordam K, et al. High prevalence of testicular adrenal rest tumors, impaired spermatogenesis, and Leydig cell failure in adolescent and adult males with congenital adrenal hyperplasia. J Clin Endocrinol Metab 2001;86:5721-8.

4. Merke DP. Approach to the adult with congenital adrenal hyperplasia due to 21-hydroxylase deficiency. J Clin Endocrinol Metab 2008;93:653-60.

5. Ambroziak U Bednarczuk T, Ginalska-Malinowska M, Małunowicz EM, Grzechocińska B, Kamiński P, et al. Congenital adrenal hyperplasia due to 21-hydroxylase deficiency management in adults. Endokrynol Pol 2010;61:142-55.

6. Juul A. Testicular adrenal rest tumours in boys, adolescents and adult men with congenital adrenal hyperplasia may be associated with the CYP21A2 mutation. Int $\mathrm{J}$ Androl 2010;33:521-7.

7. Claahsen-van der Grinten HL, Hulsbergen-van de Kaa CA, Otten BJ. Ovarian adrenal rest tissue in congenital adrenal hyperplasia - a patient report. J Pediatr Endocrinol Metab 2006;19:177-82.

8. Stikkelbroeck NM, Hermus AR, Schouten D, Suliman HM, Jager GJ, Braat DD, et al. Prevalence of ovarian adrenal rest tumours and polycystic ovaries in females with congenital adrenal hyperplasia: results of ultrasonography and MR imaging. Eur Radiol 2004;14:1802-6.

9. Tiosano D, Vlodavsky E, Filmar S, Weiner Z, Goldsher D, BarShalom R. Ovarian adrenal rest tumor in a congenital adrenal hyperplasia patient with adrenocorticotropin hypersecretion following adrenalectomy. Horm Res Paediatr 2010;74:223-8. 10. Val P, Jeays-Ward K, Swain A. Identificationof a novel population of adrenal-like cells inthe mammalian testis. Dev Biol 2006;299:250-6.

11. King $\mathrm{P}$, Paul A, Laufer E. Shh signaling regulatesadrenocortical development and identifiesprogenitors of steroidogenic lineages. Proc Natl Acad Sci USA 2009;106:2118590.

12. Ketata S, Ketata H, Sahnoun A, FakhFakh H,Bahloul A, Mhiri MN. Ectopic adrenal cortex tissue: an incidental finding during inguinoscrotaloperations in pediatric patients. Urol Int 2008;81:316-9.

13. Dahl EV, Bahn RC. Aberrant adrenal conticaltissue near the testis in human infants. Am J Pathol 1962;40:587-98.

14. Jeays-Ward K, Hoyle C, Brennan J, Dandonneau M, Alldus G, Capel B, et al. Endothelial and steroidogenic cell migration are regulated by WNT4 in the developing mammalian gonad. Development 2003;130:3663-70.

15. Biason-Lauber A, De Filippo G, Konrad D, Scarano G, Nazzaro A, Schoenle EJ. WNT4 deficiency - a clinical phenotype distinct from the classic Mayer-Rokitansky-Kuster- Hauser syndrome: a case report. Hum Reprod 2007;22:224-9.

16. Mouritsen A, Jorgensen N, Main KM, Schwartz M, Juul A. Testicular adrenal rest tumours in boys, adolescents and adult men with congenital adrenal hyperplasia may be associated with the CYP21A2 mutation. Int J Androl 2010;33:521-7.

17. Crocker MK Barak S, Millo CM, Beall SA, Niyyati M, Chang $\mathrm{R}$,et al. Use of PET/CT with cosyntropin stimulation to identify and localize adrenal rest tissue following adrenalectomy in a woman with congenital adrenal hyperplasia. J Clin Endocrinol Metab 2012;97:E2084-9.

18. Nagamine WH, Mehta SV, Vade A. Testicular adrenal rest tumors in a patient with congenital adrenal hyperplasia: sonographic and magnetic resonance imaging findings. J Ultrasound Med 2005;24:1717-20. 